\title{
A CONCRETIZAÇÃO DA FUNÇÃO SOCIAL DA PROPRIEDADE ÁNÁLISE JURÍDICA DO IPTU
}

\author{
LEGAL ANALYSIS OF PROPERTY TAX, THE \\ IMPLEMENTATION OF SOCIAL FUNCTION OF PROPERTY
}

\author{
Cinthia Terasaca ${ }^{1}$ \\ Dayane Souza Cunico ${ }^{2}$ \\ Emilim Shimamura ${ }^{3}$
}

\begin{abstract}
RESUMO: O presente trabalho tem como objetivo realizar uma análise crítica sobre as divergências existentes acerca do IPTU, traçando um paralelo entre o imposto em questão e os tributos que não se limitem à mera arrecadação aos cofres públicos, ultrapassando a fiscalidade, para adentrar no que a doutrina nomeia extrafiscalidade. Destina-se, a extrafiscalidade, a promover o dever jurídico pela Constituição Federal imposto à propriedade, dever de atender à função social. Deste modo, a pesquisa desenvolveu-se a partir da análise desse princípio maior destinado a orientar e limitar o direito individual de propriedade, realizando algumas pontuações sobre a importância do IPTU na promoção de políticas urbanas. Tratou-se das legislações pertinentes ao tema, previstas na Constituição Federal, Código Tributário Nacional e Estatuto da Cidade, entre outras. Foram ainda tecidas breves considerações históricas acerca do Imposto Predial e Territorial Urbano, contextualizando-o quanto à sua regra-matriz, para demonstrar seus componentes - hipótese tributária e seus respectivos critérios e relação jurídica tributária - e descrever, com maior vagar, o critério que efetivamente interessa à apreciação da extrafiscalidade, qual seja, o componente quantitativo. Derradeiramente, adentrou-se especificamente a extrafiscalidade, conceituando-a, apontando suas modalidades, finalidades e controvérsias.
\end{abstract}

Palavras-Chave: Propriedade; Progressividade Extrafiscal; Função Social; IPTU.

\begin{abstract}
The current work has as its object to make an analysis over IPTU considering the necessity to relate it to other forms of acting that don't limit only the gathering of tributes to the public safes, trespassing, therefore, the mere taxation, to get into what the doctrine has denominated extrafiscality. This other form of taxing promotes the social function of property. So, the research has developed itself from the analysis of the property's social function, making some punctuations over the importance of the tax to the promotion of urban politics, of the Brazilian cities' directive plans, as well as the regulations brought up by the Federal Constitution and the City's Statute. Brought some historical considerations abroad the tribute, contextualizing it on what concerns to its matrix-rule, in a way of showing the tax hypothesis in its respective criteria, until it gets to the quantity, having in mind the extrafiscality takes into consideration the altering on the ratings. Therefore, approaches the issue of the extrafiscality, giving its concept, pointing its modalities, finalities and controversies.
\end{abstract}

Key-words: Property; Extrafiscal Progressivity; Social Function; IPTU.

\footnotetext{
${ }^{1}$ Acadêmica do $5^{\circ}$ ano de Direito da Universidade Estadual de Londrina.

${ }^{2}$ Acadêmica do $5^{\circ}$ ano de Direito da Universidade Estadual de Londrina.

${ }^{3}$ Acadêmica do $5^{\circ}$ ano de Direito da Universidade Estadual de Londrina.
} 


\section{INTRODUÇÃO}

O objeto primordial deste estudo é analisar, de forma tênue, os parâmetros impostos pela Constituição Federal ao uso da propriedade, utilizando como instrumento exemplificativo o IPTU. Nesta esteira, discutir a progressividade das alíquotas que comporão o critério quantitativo da hipótese de incidência do Imposto Predial e Territorial Urbano torna-se imprescindível, uma vez que através destas poder-se-á verificar a satisfação do princípio constitucional que limita o direito de propriedade.

Inicialmente será reservado um capítulo para conceituar Função Social, de onde serão extraídas breves considerações sobre a importância da extrafiscalidade como instrumento para viabilizar políticas urbanas sociais. Proceder-se-á à análise da Função Social no ordenamento jurídico brasileiro, traçando um paralelo entre este dever constitucional e os desdobramentos da progressividade do IPTU, como forma de viabilizar a premissa dos limites impostos ao direito individual de propriedade. Serão realizados ainda alguns apontamentos sobre o Estatuto da Cidade e o Plano Diretor.

Ulteriormente, procurou-se descrever todos os componentes da norma de incidência fiscal afeta ao IPTU, identificando os critérios atinentes à hipótese tributária e à relação jurídica obrigacional por esta hipótese imposta. Entre os aludidos critérios, o estudo em pauta deteve-se, sobremaneira, ao conseqüente da norma abstrata geral, qual seja, o critério quantitativo.

Finalmente, tratou-se da identificação da progressividade no IPTU, da extrafiscalidade como instrumento promotor de resultados econômicos, políticos e sociais; e das controvérsias doutrinárias e jurisprudenciais que versam sobre o tema. Incumbe lançar mão dos escritos para compreender a relevância e atualidade da pesquisa que se propôs a desenvolver.

\section{A FUNÇÃO SOCIAL DA PROPRIEDADE}

O princípio da função social da propriedade traz ao debate jurídico o tema da relativização dos direitos individuais, uma vez que aquela deixa de ter estrita vinculação aos interesses isolados do proprietário para atender a determinadas finalidades sociais, segundo o qual, o seu uso, deve prestar-se também ao serviço do bem comum.

Neste sentido, Eros Grau entende a necessária distinção entre direito individual e função social, em suas palavras: 
Fundamentos distintos justificam propriedade dotada de função individual e propriedade dotada de função social. Encontra justificação, a primeira na garantia, que se reclama, de que possa o indivíduo prover a sua subsistência e de sua família, daí porque concorre para essa justificação a sua origem, acatada quando a ordem jurídica assegura o direito de herança. Já a propriedade dotada de função social, é justificada pelos seus fins, seus serviços, sua função (GRAU apud SAULE JÚNIOR, 2002, p. 82).

Verifica-se, de tal assertiva, que ambos guardam vinculação a fundamentos constitucionais, contudo, não há mais que se falar em um direito individual absoluto, haja vista, que o Estado poderá intervir na esfera de autonomia privada, no que pese a propriedade, desde que esta não observe os regramentos de sua função social, ou seja, se ela deixar de atender a finalidade do bem comum.

Segundo Pedro Escribano Collado, citado por José Afonso da Silva, a função social “introduziu, na esfera interna do direito de propriedade, um interesse que pode não coincidir com o do proprietário e que, em todo caso, é estranho ao mesmo", e isto fez com que, a própria noção sobre o significado de propriedade viesse a sofrer alterações significativas, pois, segundo José Afonso da Silva (2003, p. 275), modificou a sua natureza, uma vez que a idéia de função social passou a incorporar-se ao próprio conteúdo do conceito de propriedade, qualificando o modo de sua aquisição, gozo e uso (COLLADO apud SILVA, 2003, p. 274).

Neste contexto, a propriedade, uma vez permeada pela sua função social, passa a ser um meio de promoção de justiça e ganha novas regulamentações jurídicas, não apenas nos diversos dispositivos constitucionais que norteiam a matéria, mas sobretudo, na previsão de leis infraconstitucionais que lhe garantem a efetividade.

O IPTU, neste sentido, é um dos importantes instrumentos para promoção de políticas urbanas, no que pese a sua função extrafiscal, uma vez que a Constituição Federal de 1988, o Estatuto da Cidade e os Planos Diretores dos municípios passaram a regular a função social da propriedade por meio de suas alíquotas.

\section{PREVISÕES DA FUNÇÃO SOCIAL DA PROPRIEDADE NO ORDENAMENTO JURÍ- DICO BRASILEIRO}

Cabe ressaltar que a previsão da Função Social da Propriedade no ordenamento jurídico brasileiro é ampla e pode ser analisada tanto pelo viés da propriedade rural, como urbana, entre outros aspectos não relativos a propriedade. No estudo em questão, cabe a análise em 
torno da propriedade urbana, tendo em vista que somente esta compreende a natureza jurídica do IPTU.

A título de esclarecimento, no entanto, a função social da propriedade poderia ser entendida sob o seu aspecto rural, atendendo, neste caso, às políticas agrícolas relativas aos artigos 187 e 188 da CF/88, ou através de políticas fundiárias presentes nos artigos 184, 185, 186, 189, 190 e 191 da referida Carta. Pode, ainda, ser analisada, pelo seu aspecto econômico através do artigo 180, I e 170; ambiental através do artigo 186, II e trabalhista no 186, III, todos da Constituição Federal.

Cabe analisar, todavia, como já dito, o seu aspecto urbano, que no caso do IPTU a previsão sobre sua função social diz respeito a extrafiscalidade do imposto, que fora devidamente prevista pela Constituição Federal de 1988, o Estatuto da Cidade e, para alguns municípios brasileiros, em seu Plano Diretor.

$\mathrm{Na}$ Constituição Federal, o princípio encontra abrigo em seus artigos $156, \S 1^{\circ}$, II, que trata da extrafiscalidade através da aplicação de alíquotas diferentes de acordo com a localização e uso do imóvel, desde que presentes tais disposições no plano diretor, e $182, \S^{\circ}$, II, que prevê a incidência de alíquotas progressivas em razão do tempo (CARRAZA, 2008, p. 118).

No Estatuto da Cidade, denominação genérica para a Lei federal nº 10.257/01, há previsão sobre a função social da propriedade em seus diversos dispositivos, restringindo-se à matéria do IPTU em seu artigo $7^{\circ}$. Tal disposição veio a atender a necessidade trazida pelo artigo $182, \S 4^{\circ}$, II da CF, que permite a progressão de alíquotas extrafiscais em razão do tempo, mas, todavia, trouxera a expressão "nos termos da lei federal”, o que abriu discussão se o município poderia prever em seus planos diretores a incidência destas alíquotas, sem que houvesse, no entanto, a existência de uma lei federal.

Contudo, em 2001, sobreveio o Estatuto da Cidade para regular a matéria, oferecendo diretrizes gerais para os Planos Diretores, no sentido de viabilizar a função social da propriedade quanto a não utilização, subutilização ou não edificação de solo urbano.

Por fim, no município de Londrina, na Lei Orgânica $n^{\circ}$ 7.303/97, em seu artigo 175, de acordo com a tabela III, previu a progressividade extrafiscal em razão do tempo, contudo, há discussões quanto a constitucionalidade da referida tratativa, celeuma a ser analisada mais a frente. 


\section{A EXTRAFISCALIDADE COMO INSTRUMENTO PARA PROMOÇÃO DE POLÍTI- CA URBANA}

A promoção de políticas urbanas voltadas a finalidades sociais ganha importância à medida em que crescem as injustiças, a desordem e a necessidade de ser preservado um meio ambiente saudável.

Neste sentido, cabe ao Poder Público regular a função social da propriedade, como comenta Regina Helena Costa (2003, p. 103), através do planejamento dos municípios em atenção ao que é ou não prioritário. Isto se dará mediante a utilização de determinados instrumentos, tal como o plano diretor. Em suas palavras:

\footnotetext{
A definição do conteúdo da função social a ser cumprida pela propriedade imóvel fez remeter ao plano urbanístico. Esse é o instrumento do planejamento urbanístico, assim entendido como o meio pelo qual o Poder Público pode orientar e racionalizar a atuação urbanística, direcionando-as às áreas consideradas prioritárias. Exemplo típico de plano urbanístico é o plano diretor, qualificado constitucionalmente como instrumento básico de desenvolvimento e de expansão urbana, obrigatório para cidades com mais de vinte mil habitantes (art. 182, $\S 1^{\circ}$ e $2^{\circ}$, da CF) (COSTA, 2003, p. 103).
}

Assim, para que se possa compreender a relação entre as políticas urbanas e a extrafiscalidade, necessário aclarar o que venha a ser urbanismo e direito urbanístico, para depois demonstrar que, através da extrafiscalidade, há um ponto de convergência entre o direito urbanístico e o direito tributário, união indispensável para a efetividade da função social da propriedade.

Neste sentido, urbanismo "é o conjunto de medidas estatais destinadas a organizar os espaços habitáveis, de modo a propiciar melhores condições de vida ao homem na comunidade"(COSTA, 2003, p. 102). Por outro lado, direito urbanístico "compreende o conjunto de normas jurídicas reguladoras da atividade do Poder Público destinada a ordenar espaços habitáveis" e, vale lembrar, que o princípio que informa o direito urbanístico é o da função social da propriedade (COSTA, 2003, p. 102).

Feitas estas considerações, é possível verificar a intersecção entre o direito urbanístico e o direito tributário, que segundo a referida autora, "o ponto de toque entre ambos é a extrafiscalidade" (COSTA, 2003, p. 104).

A extrafiscalidade, segundo Geraldo Ataliba, citado por Costa, consiste em uma forma 
não arrecadatória de tributar, uma vez que sua finalidade não visa a geração de recursos para o Estado, mas estimular, induzir ou inibir comportamentos, tendo em vista a realização de valores consagrados pela Constituição. Neste contexto, o IPTU, como será visto nos próximos pontos, é um instrumento eficaz para persecução de finalidades sociais e promoção de políticas urbanas, ou seja, para realizar a função social da propriedade (ATALIBA apud COSTA, 2003, p. 104).

\section{COMENTÁRIOS ACERCA DO ESTATUTO DA CIDADE E DO PLANO DIRETOR}

Como visto, o Poder Público regula a função social da propriedade através do planejamento urbano municipal e o plano diretor é atualmente um de seus principais instrumentos. Cumpre ressaltar, que a extrafiscalidade do IPTU somente poderá ocorrer se estiver de acordo com as diretrizes gerais trazidas pelo Estatuto da Cidade, contudo, a matéria é controversa.

Carrazza (2008, p. 128), por exemplo, ao contrário do que dispõe o referido Estatuto, entende que o município não estaria condicionado à lei federal (Estatuto da Cidade), no que pese as diretrizes de seu artigo $7^{\circ}$, uma vez que o considera inconstitucional, tendo em vista que lei federal editou regras ao município, invadindo seu campo de atuação.

Contudo, o Estatuto da Cidade traz diretrizes gerais, o que levaria a sua equiparação como lei complementar. Além disso, a jurisprudência vem entendendo que a não observância ao Estatuto, no que pese a extrafiscalidade do seu art. $7^{\circ}$, pelo Plano Diretor municipal, acarreta em ilegalidade, como o caso que ocorreu no município de Londrina, situação a ser posteriormente comentada.

No momento, cabe apenas analisar a importância da referida lei, uma vez que regula questões de ordem pública e interesse social, quanto ao uso da propriedade urbana, "em prol do bem coletivo, da segurança e do bem-estar dos cidadãos", como estabelece seu artigo $1^{\circ}$, parágrafo único (COSTA, 2003, p. 101).

Assim, o Estatuto da Cidade nasce como meio para promoção do direito às cidades sustentáveis, que no seu artigo $2^{\circ}$, inciso $\mathrm{I}$, assim conceitua “o direito à terra urbana, à moradia, ao saneamento ambiental, à infra-estrutura urbana, ao transporte e aos serviços públicos, ao trabalho, ao lazer, para as presentes e futuras gerações" (COSTA, 2003, p. 107).

A tônica, portanto, do Estatuto da Cidade é o interesse social, e irá nortear o Plano Diretor segundo princípios e diretrizes políticas urbanas, destacando-se, a garantia de direito a cidades sustentáveis, a gestão democrática por meio de participação popular, à justa distribuição dos benefícios e ônus decorrentes do processo de urbanização, a regularização fundiária 
e urbanização de áreas ocupadas por população de baixa renda, e, que para o presente estudo, interessa saber:

\footnotetext{
Ordenação e controle do uso do solo, de forma a evitar: a utilização inadequada dos imóveis urbanos, o parcelamento do solo, a edificação ou o uso excessivo ou inadequados em relação à infra-estrutura urbana, a retenção especulativa de imóveis urbanos, que resulte na sua subutilização ou não utilização, a deterioração de áreas urbanizadas (SAULE JÚNIOR, 2002, p. 80).
}

Deste modo, tanto o Estatuto da Cidade, bem como os Planos Diretores dos municípios brasileiros são instrumentos determinantes para o desenvolvimento de política urbana e a utilização do IPTU, neste contexto, na sua modalidade extrafiscal, torna-se um poderoso meio para a promoção de justiça social.

\section{IPTU}

As raízes do Imposto Predial e Territorial Urbano encontram-se em 1808. Primeiramente o imposto foi denominado Décima Urbana, após algumas transformações sobre sua incidência e competência chegou-se às previsões descritas na Constituição Federal de 1988, que firmou a autonomia municipal e garantiu ao Município a competência para instituir, arrecadar e fiscalizar o tributo hoje conhecido como IPTU (FURLAN, 2008, p. 47).

\section{LEGISLAÇÃO}

As legislações pertinentes ao IPTU são: Constituição Federal, Código Tributário Nacional, Decreto-Lei 57/66, Estatuto da Cidade e Leis Municipais.

A Constituição Federal trata do referido imposto no seu art. 156, I, estabelecendo que: "Compete aos Municípios instituir impostos sobre: I - propriedade predial e territorial urbana.”.

O Código Tributário Nacional, por sua vez, em seu artigo 32 expande o critério espacial veiculado pela Norma Constitucional ao veicular como passíveis de incidência do IPTU os institutos do domínio útil e da posse.

Com o advento do Decreto-Lei 57/66, passou-se a estabelecer critérios para reconhecer o que seria zona urbana e zona rural. Com o Estatuto da Cidade passou-se a estabelecer 
diretrizes gerais direcionadas à criação de um Plano Diretor para os Municípios, com o objetivo de implementar a função social à propriedade.

Por fim, as Leis Municipais cuidaram de instituir direcionamentos efetivos à criação de um Plano Diretor necessário a Municípios que possuíssem mais de vinte mil habitantes.

\section{CRITÉRIOS}

Precedentemente à análise dos critérios presentes na norma concreta geral afeta ao IPTU, importante lembrar a Regra-matriz de incidência fiscal dos impostos.

De acordo com o doutrinador Paulo de Barros Carvalho, a regra matriz é composta de Hipótese Tributária, que comporta os critérios material, espacial e temporal; e Relação Jurídica Tributária, cujos critérios integrantes são de caráter pessoal e quantitativo (CARVALHO, 2008, p. 259, 260).

Tendo isto em vista, caminhar-se-á para o estudo de cada um desses componentes acima declinados, iniciando-se pelos critérios da Hipótese Tributária, prosseguindo aos critérios da Relação Jurídica Tributária.

\section{HIPÓTESE TRIBUTÁRIA}

A hipótese tributária consiste em uma descrição legal de um evento, que, por interessar ao mundo do direito, é alçado a fato jurídico tributário. Trata-se do fenômeno da subsunção do evento ao mundo do direito. (ATALIBA, 2009, p. 58).

\section{CRITÉRIO MATERIAL}

Se refere ao comportamento de uma pessoa, condicionado por circunstâncias de espaço e de tempo, representada por um verbo e seu complemento, não devendo ser confundida com a descrição objetiva de fato, que seria obtido da composição da hipótese tributária (CARVALHO, 2008, p. 285, 287).

A Constituição Federal em seu art. 156, I determina, como já mencionado, ser competência dos Municípios a instituição de impostos sobre propriedade predial e territorial urbana, sendo o critério material preenchido por um indivíduo que for proprietário.

O CTN, em seu artigo 32, no entanto, manteve as orientações da Constituição Federal reiterando a competência dos municípios sobre, mas ampliou o critério material para abranger 
a propriedade, o domínio útil ou a posse de bem imóvel por natureza ou por acessão física, localizado em zona urbana.

Destarte, vislumbra-se, como já dito, uma expansão do critério material, ao atribuir à competência municipal o direito de instituir impostos não apenas sobre o sujeito que detiver a propriedade predial e territorial urbana, mas sobre o detentor de domínio útil e da posse (FURLAN, 2004, p. 71 e 72).

\section{CRITÉRIO ESPACIAL}

O critério espacial indica circunstâncias de lugar contidas na hipótese tributária, circunstâncias estas relevantes na configuração do fato imponível. (ATALIBA, 2009, p. 104).

Relevante proceder a uma breve análise das legislações que discursam sobre o critério espacial, tratando das divergências quanto ao que se compreende como zona urbana para efeitos de incidência do IPTU.

Em 25 de outubro de 1966 publicou-se Código Tributário Nacional, que definiu, a partir de seu art. 32, que o IPTU seria devido aos imóveis que se encontrassem localizados em zona urbana, estabelecendo deste modo, a localização do imóvel para incidência do imposto.

Em 18 de novembro de 1966, no entanto, adveio o Decreto-Lei 57/66, que elegeu, por meio de seus artigos 14 e 15, a destinação do imóvel como parâmetro para definição de zona urbana e rural.

A Emenda Constitucional 1/69, por sua vez, deu status de lei complementar ao CTN e ao Decreto descrito ao estabelecer que apenas Leis Complementares poderiam tratar de normas gerais de Direito Tributário, sendo ambos os diplomas recepcionados pela Constituição Federal.

Entretanto, por serem dois institutos de mesma hierarquia, leis complementares, subsistiu a indagação sobre qual prevaleceria em detrimento do outro. O entendimento corrente no STJ e STF é no sentido de que o Decreto-Lei, por ser legislação posterior, teria revogado o CTN em seu artigo 32. A doutrina majoritária, contudo, ratifica que o critério da destinação do imóvel para definir o que seria zona urbana e rural concede demasiada discricionariedade ao contribuinte, que poderia escolher qual imposto pagar (ITR ou IPTU) mediante simples declaração de que, por utilizar parte do terreno para o plantio, por exemplo, poderia optar pelo recolhimento do ITR, menos oneroso (FURLAN, 2008, p. 56 e 57).

O Município de Londrina, seguido o CTN, declarando, em seu artigo 164, ser a localização o critério para pagamento do IPTU. 


\section{CRITÉRIO TEMPORAL}

O critério temporal pode ser definido, por meio de explicação do doutrinador Paulo de Barros Carvalho, como as indicações que possibilitam saber em que instante o fato ocorreu, criando assim, um liame jurídico que une devedor e credor em torno de uma obrigação tributária (CARVALHO, 2008, p. 292).

No caso do IPTU, o critério temporal representa o momento em que nasce o direito subjetivo e o dever jurídico de pagar o tributo, competindo ao legislador municipal estipular a data que em se considera existente o evento que enseja a hipótese tributária. A incidência do IPTU pode ser bienal, semestral, trimestral, contudo, via de regra, o ano civil é o escolhido para marcar o critério temporal, portanto, $1^{\circ}$ de janeiro de cada ano (FURLAN, 2008, p. 92).

\section{RELAÇÃO JURÍDICA TRIBUTÁRIA}

A relação jurídica tributária, por sua vez, caracteriza-se como um vínculo no qual o sujeito ativo tem o direito subjetivo de exigir do sujeito passivo que cumpra o dever jurídico de adimplir os tributos que por este são devidos (CARVALHO, 2008, p. 314).

A relação jurídica tributária é composta por critério pessoal e critério quantitativo, estabelecendo quem deve pagar e o quantum devido.

\section{CRITÉRIO PESSOAL}

O critério pessoal designa os sujeitos da obrigação tributária. O sujeito ativo é o titular do direito de exigir a prestação pecuniária, no caso do IPTU, o Município. O sujeito passivo, por sua vez, compreende aquele que detém a propriedade, o domínio útil ou a posse, sendo o contribuinte ou o responsável, às expensas do artigo 121 do CNT (FURLAN, 2004, p. 79 e 80).

O contribuinte é aquele que realiza o fato imponível, sendo a pessoa que se encontra na situação descrita na hipótese tributária. O responsável, por sua vez, embora não esteja investido na qualidade de contribuinte e não tenha relação com o fato tributário, assume a obrigação por disposição expressa de lei (FURLAN, 2004, p. 82).

O CTN prevê a possibilidade de responsabilidade dos sucessores (art. 129 a 133) e de terceiros (art. 134 e 135), sendo estes últimos considerados como responsáveis solidários. 


\section{CRITÉRIO QUANTITATIVO}

O critério quantitativo torna possível precisar a quantia devida a título de tributo. Para que se chegue ao valor da dívida é necessário obter a base de cálculo, para ulteriormente, sobre esta, aplicar-se a alíquota pertinente (CARVALHO, 2008, p. 356).

A base de cálculo é atributo da hipótese que serve para oferecer a dimensão real do fato, fornece dados para se saber o quantum devido. No caso do IPTU, dispõe o art. 33 do CTN, que a base de cálculo constitui o valor venal do imóvel.

O valor venal do imóvel pode ser encontrado pela aferição do valor do terreno, aplicando-se a ele fatores que incidirão sobre o valor inicial do metro quadrado. O Município de Londrina, por exemplo, ela em conta a topografia, a pedologia e a situação do terreno $\left(\operatorname{art.} 2^{\circ}\right.$ da Lei Municipal de Londrina ${ }^{\circ}$ 8672/2001), para se alcançar o valor venal do imóvel, caso não esteja edificado.

Mediante este valor, incidirão outros, como na hipótese de existir edificação na propriedade. A Lei de Londrina determina que, ao valor do terreno deve-se somar o valor da construção, sendo que este segundo consiste na multiplicação da área construída pelo respectivo valor da edificação, se casa, apartamento, galpão (ex.: o valor do metro quadrado para uma casa é de $\mathrm{R} \$ 350,00)$. A este resultado deve-se multiplicar coeficientes constantes em lei, que verificam as condições do imóvel, os luxos neste presentes (ar-condicionado, piscina, elevador), chegando, por fim, à soma final: valor da construção mais o valor do terreno $=$ valor venal do imóvel base de cálculo.

A alíquota multiplicada à base de cálculo permite chegar ao valor da dívida, correspondendo, portanto, a uma fração desta base de cálculo.

As alíquotas podem ser proporcionais: alíquota constante e base de cálculo variável; progressivas: aumenta a base de cálculo, aumenta a alíquota; regressivas: aumenta a base de cálculo, diminui-se a alíquota (FURLAN, 2004. p. 113 a 115).

De acordo com a Constituição Federal, no entanto, deve-se obedecer ao princípio da capacidade contributiva ao se estabelecer tais alíquotas, devendo, para tanto, serem as alíquotas progressivas, progressividade fiscal. Quando, entretanto, existe outra progressividade, que se pode denominar extrafiscal, as alíquotas são utilizadas para compelir ou inibir o contribuinte a um determinado comportamento, situação na qual não se leva em conta a capacidade contributiva, mas a função social que deve estar impressa no direito de propriedade (CARRAZZA, 2009, p. 116). 


\section{PROGRASSIVIDADE EXTRAFISCAL}

O presente ponto visa tratar de modo mais específico a questão da extrafiscalidade, para tanto, necessário se fez a delimitação de seu conceito e características, a diferenciação de suas modalidades, para enfim, discutir as controvérsias jurídicas sobre o tema.

\section{Conceito e características da progressividade}

Consoante descrição realizada no tópico precedente, que brevemente diferenciou o instituto da Progressividade sob uma visão Fiscal e Extrafiscal, incumbe retomar o assunto para tratar, mais detidamente, da Extrafiscalidade.

É certo que os conceitos de Fiscalidade e Extrafiscalidade relacionam-se com a finalidade do tributo, ou seja, ligam-se com o propósito constitucional ao concebê-lo e ao traçar-lhe as linhas básicas. Contudo, quando sobrevém a indagação sobre o fim a que se destina um tributo, é comum a assertiva de que o objetivo precípuo desta prestação pecuniária é carrear recursos aos cofres estatais. Inexiste equívoco nesta afirmação, mas há bastante tempo, é possível verificar algumas espécies tributárias cuja inspiração ultrapassa a mera arrecadação, alcançando objetivo outro, qual seja, promover o controle de políticas econômicas e sociais.

Nesta perspectiva, entre as modalidades tributárias, o imposto revelar-se-á como excelente instrumento para alcançar fins diversos, na medida em que extrapola a característica de mero abastecimento dos cofres públicos, para buscar uma forma indireta de satisfazer interesses econômicos, políticos e sociais de um país.

Esse objetivo declinado, que ultrapassa a arrecadação e almeja controlar o comportamento das pessoas, dos contribuintes, para se alcançar um resultado que valide e efetive a apregoada função social defendida pela Constituição Federal, é alcançada por intermédio do critério quantitativo, expresso no conseqüente da regra matriz de incidência fiscal, precisamente, por intermédio das alíquotas. Nos dizeres da doutrinadora Valéria Furlan (FURLAN, 2004, p. 144), o aumento de alíquotas sempre ocorrerá quando presentes finalidades determinadas a serem atingidas, independentemente, pois, de qualquer eventual alteração da base de cálculo.

Logo, a Extrafiscalidade significa o emprego da tributação para fins ordinatórios, não fiscais, no intuito de disciplinar comportamentos de virtuais contribuintes, induzindo-os a fazerem ou absterem-se de fazer alguma coisa (CARRAZZA apud FURLAN, 2004, p.144). O resultado que ora se elege torna-se efetivo lançando-se mão de alíquotas diferenciadas para 
compor o dever jurídico a que está obrigado o sujeito passivo da relação jurídica tributária, ou seja, partindo-se da capacidade contributiva para fins de progressividade, e da destinação para fins de seletividade e essencialidade, é possível impor, indiretamente, ao contribuinte o dever de orientar suas ações atendendo à função social da propriedade.

Derradeiramente, plausível compelir os conceitos afirmando tratar-se a Extrafiscalidade de forma indireta de atuação do Estado que, exclusivamente por meio da tributação, visa atingir fins preponderantemente ordinatórios, com vistas a incentivar ou desestimular determinados comportamentos, afastando eventuais efeitos confiscatórios.

\section{Extrafiscalidade}

A propriedade constitui direito assegurado pela Constituição Federal, expressamente consignado em seu artigo $5^{\circ}$, XXII, contudo, não pode ser vista como garantia absoluta, uma vez que a ela são impostas limitações de natureza civil, a exemplo do direito de vizinhança; bem como restrições que visam assegurar o atendimento da função social, do bem-estar comum, amparado em princípios de ordem econômica e social.

Sob esta perspectiva, o legislador constituinte elegeu algumas formas hábeis a ressaltar o uso consciente e razoável da propriedade, entre as quais destacou a desapropriação, o respeito ao Plano Diretor do Município e a tributação extrafiscal. Logo, a Extrafiscalidade, como instrumento indireto do Estado utilizado para orientar comportamentos; se presta sobremaneira à efetivação de princípios constitucionais, que visam à manutenção da ordem econômica e à garantia de uma existência digna, assentada nos ditames da justiça social.

Cumpre verificar, de forma sucinta, algumas espécies de tributação extrafiscal. Alfredo Augusto Becker (BECKER apud FURLAN, 2004, p.149) destaca, entre as citadas espécies, os impostos proibitivos; tributos utilizados pelo legislador para, indiretamente, proibir um evento que revela uma situação ou atividade prejudicial ao bem comum, desde que a hipótese de sua incidência não ofenda o mínimo indispensável de renda ou de capital. Trata-se de um dever preestabelecido por uma regra jurídica, utilizado pelo Estado como instrumento jurídico apto a impedir ou desestimular, de forma indireta, um ato ou fato que a ordem jurídica permite. Ressalte-se que estes meios dos quais o Estado lança mão para compelir indiretamente o contribuinte a respeitar valores principiologicamente superiores, não podem assumir caráter confiscatório. Quaisquer que sejam as finalidades objetivadas mediante a instituição de impostos, não poderão estas acarretar encargos deveras acentuados a ponto de se revelarem desproporcionais ao atendimento de seus fins. 
Frise-se, os impostos proibitivos, como espécie do gênero extrafiscalidade, não podem atingir um caráter confiscatório justificado pelas premissas da busca de um bem comum ou do atendimento da função social da propriedade. Esta hipótese tornaria inócuo todo o aparelhamento constitucional vigente, que visa equilibrar direitos individuais e sociais.

Todavia, há sensível dificuldade em precisar quando a tributação assume um caráter desproporcional aos objetivos visados, haja vista que no texto constitucional não existem parâmetros que possibilitem reconhecer prontamente os efeitos ditos confiscatórios.

Paulo de Barros Carvalho (2008, p. 149) acentua:

Consistindo a extrafiscalidade no emprego de fórmulas jurídico-tributárias para a obtenção de metas que prevalecem sobre os fins simplesmente arrecadatórios de recursos monetários, o regime que há de dirigir tal atividade não poderia deixar de ser aquele próprio das exações tributárias. Significa, portanto, que, ao construir suas pretensões extrafiscais, deverá o legislador pautar-se, inteiramente, dentro dos parâmetros constitucionais, observando as limitações de sua competência impositiva e os princípios superiores que regem a matéria, assim os expressos, que os implícitos. Não tem cabimento aludir-se a regime especial, visto que o instrumento jurídico utilizado é invariavelmente o mesmo, modificando-o tão somente a finalidade de seu manejo. (Grifei)

Destarte, para instituir e majorar o Imposto Predial e Territorial Urbano deverá o legislador pautar-se no regime jurídico-constitucional específico dos impostos, ainda que os fins ultrapassem a mera arrecadação para atingir resultados outros. Imperioso que não se afaste das diretrizes constitucionais, pois, como bem asseverou o ilustre doutrinador Paulo de Barros Carvalho, não se trata de instrumento jurídico diverso, apenas as finalidades são outras que não as somente arrecadatórias, não havendo se falar em regime especial, mas devendo-se atentar para os parâmetros constitucionais.

\section{Das modalidades do instituto}

Considerando que a intervenção estatal na vida da nação é efetivada por meio de tipos normativos, no campo da tributação poder-se-á citar como exemplo desta ingerência a faculdade do Poder Executivo de alterar alíquotas visando a consecução de fins sociais, econômicos e políticos, desde que respeitados limites legalmente previstos.

Roque Antonio Carrazza (CARRAZZA, 2008, p. 118) destaca, no caso do IPTU, que a extrafiscalidade - de modo diverso da progressividade fiscal que obedece ao princípio da 
progressão de alíquotas segundo a capacidade contributiva (art. 145, $\S 1^{\circ}$ e art. 156, $\S 1^{\circ}$, ambos da CF) - tem como fundamento a realização da função social da propriedade. Para tanto, poder-se-á lançar mão de alíquotas diferentes (seletivas) de acordo com a localização e o uso do imóvel, desde que presentes tais disposições no Plano Diretor do Município (art. 156, $\S 1^{\circ}$, II da CF) que a estabelece; e de acordo com alíquotas ditas progressivas extrafiscais, aplicadas em razão do tempo de ausência de uso da propriedade (art. 182, § $4^{\circ}$, II da CF).

Enquanto o renomado doutrinador defende a existência destas espécies diferenciadas de alíquotas, expressamente previstas nos artigos $156, \S 1^{\circ}$, I e II e $182, \S 4^{\circ}$, II da Norma Fundamental, Aires Fernandino Barreto (BARRETO, apud FURLAN, 2004, p. 156) desenvolveu uma classificação amparada tão somente na progressividade no tempo, quer dizer, somente nos casos em que não restar observada a função social da propriedade exposta no Plano Diretor do Município, entrará em "cena” a progressividade extrafiscal. As outras espécies, em tese, representariam alíquotas que devem atentar para a essencialidade da propriedade.

Aires Barreto entende que, em verdade, a redação do $\S 4^{\circ}$ do artigo 156 da Constituição Federal está, de certa forma, equivocada, na medida em que o legislador não poderá instituir impostos progressivos e alíquotas "seletivas", mas deverá prever estas diferenciações por expressa determinação constitucional que assegura a função social da propriedade. Por esta razão, a progressividade extrafiscal, disposta na Constituição vigente, estaria adstrita ao tempo de uso ou desuso da propriedade, enquanto as demais espécies de alíquotas diferenciadas representariam um dever imposto ao legislador municipal de aplicar indexadores distintos para efetivar a real função que se deve estabelecer ao direito de propriedade. Cita, nesta seara, Roque Antonio Carrazza para ratificar tratar-se de um dever imposto ao legislador infraconstitucional:

$\mathrm{O} \S 1^{\circ}$ do artigo 156 da CF prescreve que o IPTU poderá ser progressivo, nos termos da lei municipal, de forma a assegurar o cumprimento da função social da propriedade. Aliás, este poderá equivale a deverá. (...) Como averbava Rui Barbosa, todo poder encerra um dever. Quando a Constituição confere a uma pessoa política um poder, ela, ipso facto, lhe impõe um dever. (...) Assim, o $\S 1^{\circ}$ do artigo 156 da CF, juridicamente interpretado, estabelece que o IPTU, além de dever obedecer o princípio da capacidade contributiva (ser progressivo em função do valor do imóvel), terá alíquotas diferentes de acordo com a localização e uso do imóvel, de forma a assegurar o cumprimento da função social da propriedade.

A título elucidativo, somente para aclarar a discussão, elenca-se a extrafiscalidade sob o aspecto da seletividade em função do uso e localização, declarada no artigo $156, \S 1^{\circ}$, II da 
Carta Suprema; e a progressividade no tempo, disposta no já mencionado artigo $182, \S 4^{\circ}$, II do diploma em comento.

Na primeira hipótese, observado o Plano Diretor do Município, a alíquota pode variar em relação ao tipo de construção, aproveitamento do terreno, localização, destinação, entre outras especificações; enquanto na segunda situação o aumento progressivo da alíquota se daria em função do tempo e da manutenção da propriedade, mau uso ou mau aproveitamento do imóvel urbano, como, por exemplo, um proprietário que persiste em manter uma indústria em bairro residencial, violando preceitos do Plano Diretor do Município, ou que persiste manter um terreno em área urbana sem qualquer construção primando pela especulação imobiliária. A alíquota, neste caso, progrediria de acordo com sua permanência. Quanto mais tempo ficar, maior esta será.

\section{DIVERGÊNCIAS DOUTRINÁRIAS - CONTROVÉRSIAS}

Entre as inúmeras discussões suscitadas acerca do IPTU e das alíquotas aplicadas à base de cálculo para compor o critério quantitativo, alíquotas estas que, como expendido, podem induzir o comportamento do contribuinte, duas delas mereceram destaque neste estudo.

A primeira diz respeito à redação expressa no artigo $182^{4}, \S 4^{\circ}$ da $\mathrm{CF}$, que prevê medidas sancionatórias para o proprietário que fizer mal uso de sua propriedade (não edificar, sub-utilizar ou não utilizar). O $\S 4^{\circ}$ do citado dispositivo encerra a seguinte discussão: Faz-se necessária existência de Lei Federal para que o Município possa instituir alíquotas "progressivas" no tempo? Outrossim, sendo promulgada a Lei Federal n. 10.257/2001 que disciplinou a matéria em seu artigo $7^{\circ}$, far-se-á obrigatória sua aplicação?

A doutrina diverge quanto às questões levantadas, entretanto, convém destacar o posicionamento de renomados doutrinadores para dirimir o assunto.

Roque Antonio Carrazza (CARRAZZA, 2008, p. 121) defende que o Município não está condicionado à Lei Federal mencionada para prever, em seu Plano Diretor, as medidas que se fizerem essenciais à efetivação da função social da propriedade. Aliás, o referido autor considera inconstitucional essa exigência, uma vez que o Estatuto da Cidade teria ditado regras ${ }^{4}$ Art. 182. A política de desenvolvimento urbano, executada pelo Poder Público municipal, conforme diretrizes gerais fixadas em lei, tem por objetivo ordenar o pleno desenvolvimento das funções sociais da cidade e garantir o bem- estar de seus habitantes.

$\S 4^{\circ}$ - É facultado ao Poder Público municipal, mediante lei específica para área incluída no plano diretor, exigir, nos termos da lei federal, do proprietário do solo urbano não edificado, subutilizado ou não utilizado, que promova seu adequado aproveitamento, sob pena, sucessivamente, de (...) 
ao Município, invadindo seu campo de atuação. Ressalta, derradeiramente, que a inexistência de Lei Federal a que faz alusão o preceituado $\S 4^{\circ}$, não inibe o Município de, com base em Lei Local, tomar as providências necessárias a empreender o bem comum à municipalidade. Deve, a reclamada Lei Federal, limitar-se a estabelecer normas gerais, sendo vedada a previsão de assuntos de interesse local, cuja competência privativa seja do Município (artigo 30, I, da Carta Suprema).

José Souto Maior Borges (BORGES, apud CARRAZZA, 2008, p. 124), partilha do mesmo entendimento, afirmando ser impossível aceitar que Lei Federal amplie ou restrinja o âmbito de discricionariedade dos Municípios. Somente estes entes possuem as informações necessárias para fixar diretrizes aptas a atender o princípio da função social da propriedade, e para concretizar o efetivo aproveitamento de sua zona urbana. Nos dizeres deste estudioso, condicionar o exercício da Lei Municipal à preexistência de Lei Federal representaria penetrar na esfera do peculiar interesse do Município, implicaria a invalidação do princípio da autonomia municipal.

Logo, interpretar a norma em questão, especificamente quanto ao seu $\S 4^{\circ}$, no sentido de aceitar a submissão da Lei Municipal à Lei Federal, afrontaria manifestamente os pressupostos do Princípio Federativo, porquanto romper-se-ia com a natureza isonômica dos entes federados, que não podem ter suas esferas de competência invadidas pela atuação das demais. Contudo, como já comentado em ponto anterior, cabe a ressalva, da importância do Estatuto da Cidade, não apenas pelo avanço que representa em matéria social, mas por tratar-se de diretrizes gerais para consecução dos planos diretores.

Outra questão que merece ressalva versa sobe a aplicabilidade das Súmulas 589 e 668, ambas do $\mathrm{STF}^{5}$. O STF declarava inconstitucional a progressividade de alíquotas do IPTU, cuja competência recaía sobre os Municípios, porque entendia tratar-se de imposto real, de caráter objetivo, para o qual interessa tão somente a matéria a ser tributada e não as condições pessoais do contribuinte, característica afeta aos impostos ditos pessoais, que aferem a capacidade contributiva. A Suprema Corte, ao não admitir, em vários julgamentos, a progressividade do IPTU, não o fez por ausência de permissão constitucional, mas em razão de tratar-se de imposto real. A sistemática oposição do STF quanto à progressividade do IPTU ensejou a edição da Emenda

\footnotetext{
${ }^{5}$ Súmula 589: É inconstitucional a fixação de adicional progressivo do imposto predial e territorial urbano em função do número de imóveis do contribuinte.

Súmula 668: É inconstitucional a lei municipal que tenha estabelecido, antes da Emenda Constitucional 29/2000, alíquotas progressivas para o IPTU, salvo se destinada a assegurar o cumprimento da função social da propriedade urbana.
} 
Constitucional 29 de setembro de 2000, que representou uma forma de correção legislativa da jurisprudência do Supremo Tribunal Federal. A referida emenda trouxe nova redação ao artigo $156, \S 1^{\circ}$, I e II da CF, para prever a instituição de alíquotas progressivas para o IPTU em razão do valor, localização e uso de imóvel.

A Súmula 668, por sua vez, tentou regularizar essa situação dispondo como inconstitucionais as leis municipais que antes da Emenda Constitucional 29/2000 tenham instituído alíquotas progressivas para o IPTU.

O Município de Londrina, em tese, teria desrespeitado esse posicionamento do STF em dois momentos. Inicialmente porque a Lei Municipal n. 7.303/97 teria previsto, em seu artigo 175, a existência de alíquotas progressivas em razão do tempo para imóveis não construídos, localizados na zona urbana, quando pertencentes a um mesmo proprietário, afrontando a referida Súmula 589. Em um segundo momento porque, sendo precedente à citada EC 29/2000, não poderia estabelecer alíquotas progressivas, seletivas ou essenciais.

O juízo da $8^{\mathrm{a}}$ vara Civil da Comarca de Londrina, em recente decisão, manifestouse sobre o embrólio outrora discutido. A questão controversa referia-se à progressividade extrafiscal de alíquotas que majoravam seu valor em razão do tempo, para imóveis não construídos. Na ocasião, fora decidido em primeira instância que o artigo 175 da Lei municipal n. 7.303/97 era inconstitucional, haja vista, que não havia previsão desta possibilidade de alíquota no plano diretor da cidade. Outrossim, foram as mencionadas alíquotas consideradas ilegais, porque os parâmetros sobre os quais incidiram não condiziam com o Estatuto da Cidade, entendendo, portanto, pela necessidade do Município estar submetido a esta lei federal (PARANÁ. 8 CÍVEL DE LONDRINA, 2009).

$\mathrm{O}$ que se infere dos fundamentos e argumentos declinados repousa sobre uma divergência já tratada: A autonomia dos entes municipais. Se apenas o Município reúne condições de, através de um Plano Diretor, fazer valer os deveres impostos pela Constituição, haja vista conhecer as deficiências de seu espaço urbano e rural e a exploração que sobre este se faz; porque não estaria apto a instituir alíquotas progressivas, seletivas e essenciais para garantir o respeito à função social da propriedade? A reverência à técnica, no que concerne à discussão da natureza pessoal ou real do tributo, não pode se sobrepor aos princípios de ordem constitucional, aos quais todo o ordenamento jurídico deve prestigiar e obedecer. 


\section{CONCLUSÃO}

O presente trabalho analisou como o IPTU, através da sua extrafiscalidade, passa a ser um instrumento eficaz para a promoção de políticas urbanas que tenham por meta a realização da função social da propriedade.

Dentro deste contexto, não haveria como abordar a matéria sem adentrar, ainda que de modo breve, na relação existente entre o direito urbanístico e o direito tributário, haja vista, que o ponto de encontro destas diferentes áreas está justamente alicerçado na questão da extrafiscalidade, pois, de um lado o direito urbanístico, que tem como norte a realização da função social da propriedade, necessita de instrumentos palpáveis para tal fim, o direito tributário por sua vez, que tem o IPTU, na sua modalidade extrafiscal, como meio legal para sua realização, necessita do direito urbanístico para delimitar como a aplicação deste imposto pode ser realizada para promoção de políticas urbanas desejáveis.

Além disso, com o intuito de contextualizar o IPTU em sua estrutura tributária, no que pese a regra-matriz de incidência fiscal, foram tratados todos os critérios pertinentes ao referido imposto, com destaque ao critério quantitativo, tendo em vista que a extrafiscalidade pressupõe a alteração na alíquota, podendo esta ser seletiva ou diferente de acordo com o uso e localização do imóvel, como progressiva no tempo, para os casos em que o poder público prevê medidas sancionatórias para o proprietário que não utilizar ou subutilizar o imóvel.

Por derradeiro, a pesquisa buscou identificar o conceito e principais características da extrafiscalidade do IPTU, sobretudo quanto a sua destinação social, portanto não vinculada a mera arrecadação de tributos aos cofres públicos, o que a diferencia da forma fiscal. Ainda, buscou-se aclarar as suas duas modalidades, qual seja, em função do tempo, e em razão do uso e localização.

Por fim, foram levantadas discussões doutrinárias e jurisprudenciais acerca de pontos controvertidos, como a questão da autonomia municipal frente a necessidade do plano diretor estar ou não submetido ao Estatuto da Cidade que, se de um lado tem-se reconhecidos doutrinadores que entendem pela autonomia dos municípios, por outro, na prática, tendo em vista entendimento jurisprudencial, há necessidade de serem atendidos os preceitos trazidos pela lei federal. 


\section{REFERÊNCIAS}

ATALIBA, Geraldo. Hipótese de Incidência Tributária. São Paulo: Malheiros, 2003.

CARRAZZA, Roque Antonio. Curso de direito constitucional tributário. São Paulo: Malheiros, 2008.

CARVALHO, Paulo de Barros. Curso de Direito Tributário. São Paulo: Saraiva, 2008.

COSTA, Regina Helena. Instrumentos tributários para implementação da política urbana (art. $7^{\circ}$ ). In: DALLARI, Adilson Abreu; FERRAZ, Sérgio (Coord.). Estatuto da cidade: comentários à lei federal 10.257/01. São Paulo: Malheiros, 2003.

FURLAN, Valéria. Imposto Predial e Territorial Urbano. São Paulo: Malheiros, 2004.

PARANÁ. 8a VARA CÍVEL DE LONDRINA. Mandado de segurança n. 537/09. Apelante: Mavillar. Apelado: Secretário da fazenda do município de londrina. Juiz: José Ricardo Alvarez. Londrina, 01/09/2009. Disponível em $<\mathrm{http}$ ://www.assejepar.com.br/cgibin/det_processo_dire-

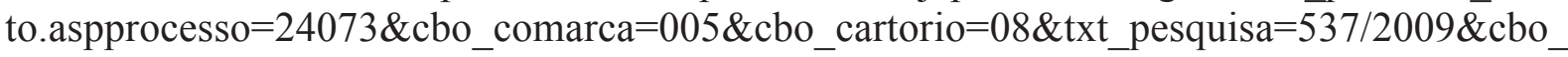
pesquisa $=1 \&$ rdo_tipo_pesquisa $=1 \&$ direto $=S>$ Acessado em 15/11/2009.

SAULE JÚNIOR, Nelson. Estatuto da cidade e o plano diretor: possibilidades de uma nova ordem legal urbana justa e democrática. In. OSÓRIO, Letícia Marques (Org.). Estatuto da cidade e reforma urbana: novas perspectivas para as cidades brasileiras. Porto Alegre: Fabris, 2002.

SILVA, José Afonso. Curso de direito constitucional positivo. São Paulo: Malheiros, 2003. 